\title{
Writing short stories to describe literary language use and perceptions as writer ${ }^{1}$
}

\section{Escritura de historias cortas para describir el uso del lenguaje literario y las percepciones como escritor.}

\author{
José Alonso Hernández Martín² \\ Universidad El Bosque - Bogotá \\ Secretaría de Educación Distrital de Bogotá \\ jahernandez1975@gmail.com
}

Received: March 1, 2017

Accepted: April 11, 2017

How to cite this article (APA, 6th ed.): Hernández-Martín, J. (2017). Writing short stories to describe literary language use and perceptions as writer. Enletawa Journal, 10 (2), 13 - 28

\begin{abstract}
This qualitative case study aims at describing the process followed by ninth grade students at a private religious school when using and analyzing literary language. The instruments used to carry out this study were: students' artifacts to identify and analyze the literary language used, field notes, and interviews. During this process, the learners as authors generated the construction of meaning and developed their competence in writing. The results show that students used metaphors and similes (literary features) to express ideas and details about their contexts in written production. In turn, students profited from the poetic function of the language where their voices as authors describe their perceptions and experiences as writers.

1 Research report

2 José Alonso Hernández Martín holds a B.A. in Modern Languages from La Salle University and M.A. in Applied Linguistics in TEFL from Universidad Distrital Francisco José de Caldas. He is an English teacher at a Public High School in Bogotá and a professor at Universidad El Bosque. He has been working as Coordinator of Pedagogical Practices in the Bilingual Education Program.
\end{abstract}


Key words: Writing competence, literary language, perception as writers, short story.

\section{Resumen}

Este estudio de caso cualitativo busca describir el proceso que estudiantes de noveno grado de un colegio privado religioso siguieron cuando escribieron sus historias cortas a través del uso y del análisis del lenguaje literario. Los instrumentos usados para llevar a cabo este estudio fueron: las producciones escritas de los estudiantes para identificar y analizar el lenguaje literario usado, notas de campo y entrevistas. En este proceso, los estudiantes como autores, generaron la construcción de significado y desarrollaron la competencia escritora. Los resultados muestran que los estudiantes usaron metáforas y símiles (elementos literarios) para expresar ideas y detalles acerca de sus contextos en la producción escrita, beneficiándose de la función poética del lenguaje donde sus voces como autores describen sus percepciones y sus experiencias como escritores.

Palabras clave: Competencia en escritura, lenguaje literario, percepción como escritores, historia corta. 


\section{Introduction}

The intention of this study is to provide insights on how to foster literary language use when students write short stories within the classroom as a means to develop the writing competence and perceptions as writers in English as a foreign language. The use of literary language conceives the expression of ideas that take into account the characteristics of literature (O'Donoghue, 2001). From this perspective, teachers gain awareness on students' writing abilities, thoughts and interests. In writing, students must consider their audience, which can make written expression challenging. This study demonstrated that the field of literature could foster the writing process among students. As writing is a means of describing human experience and feelings, learners can identify themselves with literature and interpret their own reality.

It is also important to consider literature as a means of developing the writing process and self-perceptions of one's own context. Such was the case when focusing on short stories written by a group of ninth graders. The short stories written by the participants of this research are conceived as a manifestation of the creative expression in English as a foreign language and a meaningful activity to explore literary language as a way of expression and interpretation.

\section{Statement of the problem}

Writing often responds to uninteresting instructions focused on grammatical aspects and structure of the text. This is why it is understood as a nonsense activity, as Sharples (1996) suggested, "so as well as being novel, writing must also be appropriate to the task and to the audience, otherwise it degenerates into a ramble of nonsense" (p. 3). In congruence with this point of view, teachers often do not know how to guide and foster writing. Most of the times, teachers and students are interested on grammar use and accuracy in conveying meaning using language to describe realities and concepts.

Because of the above, this research aims at describing the process followed by ninth graders in writing short stories using literary language to perceive their contexts. It was also important to analyze which features of literary language are present in ninth graders' short stories. Regarding this aspect, it can be said that language learners need to develop a greater awareness towards the importance of writing and reading at school and in their daily lives. Given this need, activities and workshops were designed in order to contextualize students in their writing processes, as well as the features and elements of literature that would be used in their short stories.

\section{Theoretical Framework}

When weread a text, the information we find gives us a message and a possibility to interactand createourconcepts. According to Gee (1991), "when elementary school students approach literacy practices, it could be a benefit for pedagogical goals" (p. 86). From this perspective, the goal of 
this study is to describe how writing short stories can provide useful pedagogical support for the enhancement of the writing process. Based on the above, the following theoretical constructs were considered: Cultural settings for meaning construction, writing competence, literary language and what a Short Story is.

\section{Cultural settings for meaning costruc- tion}

Students use different tools such as speaking, graphic and written language to express thoughts and ideas in their cultural settings. Families and schools play a role in the construction of systems in cultural meanings. Written language is one of the most resourceful tools. It is considered that meanings constructed by students, whether in words or actions, are deeply social (Hicks, 1996). This helps to define practices in literacy as the general cultural ways in which people use written language in their lives. Such practices involve values, attitudes, feelings and social relationships, including how people talk about and make sense of their activities (Barton \& Hamilton, 2000).

Bakhtin (1981) affirms that meaning is elaborated in relation to a double system. First, meaning is embedded in school culture by means of a concept system. In other words, the student could have a personal interpretation of what a concept means in abstract and what it really means in a variety of contexts. This can be interpreted consistently with general principles of the system and word meaning. Second, meaning is established through a semantic differential, which is a combination of associations and procedures designed as a technique for measuring meaning. The meaning of a word is determined by the relationship it establishes with the other in a particular context of use. Thus, Osgood (2005) assured that "the structure and context play an important role when deciphering and constructing meaning" (p. 54). From this, it can be asserted that each student presents a different background from where he or she comes from. This gives a personal touch to the use of language in each student. In other words, the environment where students grow influences the way in which they construct meaning.

According to Newton (2001), social interaction ought to take place in order to promote communicative competence. This is the reason why experiences, facts and events that happen in students' lives will allow them to contextualize words, and therefore, comprehend language better. Thus, it is necessary to allow the relationship between the cognitive process and context, while accounting for different vocabularies. Therefore, teachers need to explore the interaction that takes place in the classroom and the use of the language as a result of a communicative process. As a result, it is also important to understand how learners cope with their own difficulties, which limit the comprehension process.

Literacy practices and context are important elements in the process of writing because they provide a view of the cultural settings in which we live. In this way, Freire (1998) considered literacy as a vehicle of expression and a tool for 
human liberation. From his point of view, we can discuss the possibility of literacy being liberating and powerful when used as a meta-language or meta-discourse. The reason for this is that it defines the writer as a person situated in a society.

\section{Writing competence}

According to Greenberg (1987), the concept of writing competence refers to the emphasis, the fluency, the clarity and the appropriateness of a text. When someone is writing, he or she is communicating with others by putting their ideas in print. The development of writing is important in students' language acquisition process because they can interact in real contexts, expressing any situation or interest in a communicative function. As Miller (1989) affirmed, "The concept of competence is, however, wider than any individual guideline or recommended formulae, whether they originate from educational, trainingorlead theobjectiveofexpressions" (p. 95). Therefore, teachers are required to develop and apply elements and concepts which allow students to express their particular objectives.

Eco (1992) affirmed that writing as a communicative action with others by putting ideas in print could be understood as the connection between internal comprehension of reality and interpretation of context. He also mentioned that "the text is a synonym of context and its particular implications among the speakers and hearers of any language" (p. 134). Thus, writinghelpsinexpressing communicative intentions, using ideas in certain contexts framed by communicative situations, or simply, to share thoughts using adequate and comprehensible vocabulary.

According to Butler and Turbill (1984), good writers tend to be better readers and produce more syntactically complex writing. Students learn to read and write better when the two processes are connected, and teachers must provide meaningful contexts to bring together reading and writing activities that emphasize communicative functions for genuine purposes.

The relationship between reading and writing, as common competencies and constructiveand developmental processes, implies a reflection from personal experiences to an appropriate assimilation of social and cultural background. This reflection is meant to improve the meaning and construction of texts in students. Undertaking what Cassany (1995) presented, we can find "consciousness of the writers, planning, rereading, correcting, clarity and appropriateness of a text as some strategies of composition" (p. 64) that anyone can use in their writing.

Bottomley (1998) mentioned that both reading and writing skills share similar linguistic and cognitive elements, such as lexical features, imagery, grammar, and description of words. These elements are able to help students interpret texts with comprehension and retention of information in a contextualized setting. Additionally, students can focus on clarity, organization, style, and coherence as dimensions of writing. Nevertheless, Quintero, Cortondo, Mendez, and Posada (1995) asserted that "the freedom to write creatively about any topic is closely related 
to the development of "personal voice'" (p. 127). Because of this, it is not only reasonable to provide students with the freedom to write, but also the tools needed for students to express their realities. In doing so, we may reflect on students' writing as a means to answer questions on learning and the creation of meaning.

\section{Literary language}

The term "literary language" triggers questions that may be present in the mind of readers. It is more likely to encounter literary language in literary works than in every day conversation. According to Fokkema (1985), literary codes are conceived as a set of conventions (literary elements) that are useful when reading, analyzing and writing fiction and non-fiction. This could help readers appropriately identity and define literature and literary language. There have been many interpretations given to this particular language, although none of them truly provide a meaning in terms of content or sense. Eco (1992) affirmed that literary language is defined as one which demonstrates a propensity for the use of literary elements (figures such as metaphors or similes). In other words, literary language offers a "multiplicity of meanings" (p 104). That is to say, literary language allows unlimited possibilities of expression and interpretation of reality depending on the writer. Additionally, it helps in the construction of individual realities based on personal knowledge and full of variations and perceptual changes.

Genette (1989) stated that the reader should be a critical being in all the situations and elements presented in literary texts. Readers should try to identify relationships among signs and meanings that could be understood as figures and possible allusions in particular contexts. A writer can also choose the way he or she wishes to narrate his or her story, whether it be reality or fiction. Therefore, readers must be able to understand texts, such as when readers interpret facts of the "fable" (Eco, 1981). According to the author's criteria, and even depending his or her emotional state, it is possible to navigate through the elements of literary language to produce an interpretation of the reading and meaning of the text.

Literary language can be considered as a tool to create, apply and discover the development of the writing competence, as well as a synonym for contexts and world interpretation. According to Lazar (1993), many of the features of literary language can be isolated. These characteristics can occur in other forms of discourse, although they can combine in literary texts to form a powerful and consistent effect when reinforcing the message of the text. The notion a reader gives a text is crucial in assigning meaning to it. A great variety of factors might influence the meaning that a reader confers to a text, ranging from the individual psychology of readers to the sociocultural environment. In this sense, writing focuses on events, evocations of images, and sounds which help readers learn from their realities and understand that they are able to create texts.

Literature can provide students with access to the culture of other people, and it creates an orientation towards language 
itself. Regarding this, effective readers of a literary text possess "literary competence." This means that students can develop abilities to write and interpret literary texts. They have an implicit understanding of, and familiarity with, certain conventions which allow them to take the words and convert them intoliterary meanings(Lazar, 1993). In addition, literary texts have the particularity to add new meaning to language, as well as to reveal its inherently polysemic nature. It is clear that it has an important role in the growth and evolution of communication. The planned activities that foster interest among learners in the class will challenge students to generate a range of ideas to use as starting points. Thus, the practice of writing is framed by the conception and the elements of the short story.

\section{Short Story}

Short story is commonly understood as a narrative genre that shows the daily life of people (the characters' or the author's) in relation to their historical moment or particular circumstances (Quiroga-Clare, 2003). Based on this notion, short stories take into account real events, and they are related to the literary creativity. According to Kennedy and Gioia (1999), the reading and writing of the short story is similar to the development of an athlete because reading the short story is like knowing the game, and writing allows students to actively participate in the game with consistent and meaningful practice.

The teacher must provide the field (selective short stories), make the rules clear (understanding the elements of the short story), and allow for consistent practice sessions (student writing), so that the students can be better prepared to win the game. If the field is well maintained, the rules clearly understood, and the practice sessions meaningfully kept with feedback, everyone wins in this game, especially the players (students). Students' lives can be an ample set of themes, ideas and concepts that foster the creation and the construction of their texts.

According to Dinneen and O'Connor (1983), the short story may have a "theme", or several "themes", but it will not be an explicit illustration of a single idea, moral, or lesson. Needless to say, the point of the story is not to hammer one clear theme. Instead, writers offer readers opportunities to make their own meanings, which means that there might be many themes. Also, Dinneen and O'Connor (1983) affirmed that the form of the short story is more expansively descriptive, providing more complexity of characters, setting, and events. However, Liu (2009) explained that it is possible to recognize some of the basic elements of the short story writer's craft: plot, character, setting, point of view, and even a dash of symbolism and irony. Based on the above, it can be said that the short story is descriptive, and it provides more complexities of characters, setting, and events in which students should write for themselves and others.

The previous theoretical review provides important elements that were kept in mind when analyzing and giving concepts about meaning construction, writing competence and literary language in the creation of short stories. 


\section{Research Design}

\section{Type of study}

This is a qualitative case research study which describes and analyzes the process students went through when writing their own short stories. According to Merriam (1985), “A qualitative research is interested in understanding the meaning people construct that is how the researchers make sense of their world and the experiences they have in the world" (p. 3).

Zonabend (1992) stated that a case study is done by paying special attention to completeness in observation, reconstruction, and analysis of the cases under study. A case study research was developed because this is a particular genre of qualitative inquiry in which the researcher conducted a detailed examination of a small group of individuals. The process the individuals went through when writing their own short stories was observed and described. From this perspective, the product is an articulation of why the instance occurred as it did, and what was the most important point to explore. According to the previous ideas, a case study tries to obtain a picture, as complete as possible, of what is going on in an instance (the processes between input and output), and how the information could come from the sources and the particular observation (Yin, 1989). Taking into account the last assertion, this study is focused on how the students understood, interpreted and used the elements present in specific literary texts by authors, such as Hemmingway, Poe and Wilde, when writing their own short stories.

\section{Setting and participants}

The study was carried out at a private religious school in Bogotá, Colombia. This project was implemented with a group of 38 ninth grade female student between 14 and 16 years old. The method for participant selection was stratified random sampling. According to Anderson and Jones (1986), "researchers use stratified random sampling when populations are divided into subgroups depending on particular characteristics" (p. 18). The study began with the whole group of $9^{\text {th }}$ graders. Then, a group of ten students was selected due to their facility to wok and express ideas in English. Therefore, they demonstrated a high level of comprehension, as they obtained good results in the assessment process during the evaluations, activities and exams in the English classes. From that group of ten, a small group of 3 female students was selected as the research sample because they specifically manifested their interest in collaborating with this research. In order to guarantee the confidentiality of the participants, they were coded as follows:(S1) for student $N^{\circ} 1$, (S2) for student $\mathrm{N}^{\circ} 2$ and (S3) for student $N^{\circ} 3$. The instruments to gather data were also codified as: (IN) Interview, (FN) Field Notes and (SS) Student's Samples.

\section{Data Collection Procedures}

According to Hernandez, Fernandez and Baptista (2006), it is important to obtain a complete picture of the research participant through an accurate selection and use of different research instruments taking into account a variety of strategies. 
Some common instruments include interviews, protocol analyses, field studies, and participant observations and samples. Given the above, three instruments were used to gather data: student's artifacts (short stories), field notes and an interview.

The students' artifacts are the richest sources of data in the research project. This is because through the artifacts, we can witness what the students were able to do in terms of writing the short story, the use of literary elements, and the responses they generated to the different tasks they did. According to Hubbard and Miller (1999), one might have a good idea of what specific sets of students' work one needs to focus on in one's study. In addition, one can trace growth and notice the differences. That is to say, the use of this instrument can provide background information and understanding of issues that would not otherwise be available.

The second instrument is field notes. Through field notes, we noted what the students did during the class activities and during the workshops. This instrument provided the possibility to analyze the way they used literary elements and concepts, as well as the process they followed (in writing) according to the activities they did in class. Also, this instrument was used to describe the events that happened in class and the situations presented during the observation of the lessons. Hopkins (1995) affirms that "keeping field notes is a way of reporting observations, reflections and reactions to classrooms problems" (p. 24). In this way, field notes can help us reconstruct events, providing information about particular aspects in teaching or class behavior.
The third instrument used was an interview which could help to identify the impact of writing short stories and its activities in the classroom. In qualitative research, theinterview is a form of discourse. According to Mischler (1986), "its particular features reflect the distinctive structure and aims of interviewing, namely, that it is discourse shaped and organized by asking and answering questions" (p.36). From this perspective, we used a structured interview to gather data. In a structured interview, the evaluator asks the same questions to numerous individuals in a precise manner, offering each individual the same set of possible responses (Pawlas, 1995).

\section{Instructional Design}

In order for the students to write the short stories, three steps were followed. First of all, different workshops and class activities were carried out. Different reactions and points of view from the students in relation to the literary elements and features were observed. Then, some workshops were carried out to foster students' awareness of literary elements in order to give them elements in literary creation. Finally, students wrote their short story drafts and received teacher's and peers' feedback to improve their texts. These activities had a final purpose, which was to write a short story.

Some activities were designed to promote the development of language use, such as brainstorming, group discussion, writing and re-writing. These stages were developed with the students in order to show the literary elements (literary figures, settings, times and characters) 
and instructions that helped them in the interpretation and understanding of literarylanguageincontrasttoinstrumental language. These activities were developed during the classes, and they helped seehow the students analyzed, interpreted and worked with literary elements. Students read these literary texts: A Very Short Story (Hemingway, 1987, p. 105-108), The Black Cat (Poe, 1993.p.16-25) and The Nightingale and the Rose (Wilde, 1981). Based on these texts some workshops were carried out, as well as some sessions on sensitivity in order to give them elements in literary creation.

To follow up on students' short stories and support them in this process, an approach with different stages was followed through a typical sequence of activities, as seen below (White and Arndt, 1991):

\section{Findings}

The main purpose of this study was to describe the use of literary language by means of writing short stories as a vehicle for interpreting meaning and perception as a writer. Taking into account the previous idea and considering the main research question, how do ninth graders use literary language to write their own short stories in order to perceive their contexts? it can be asserted that students considered themselves as writers. They followed an individual process that conceives writing as a constant development of meaning construction and interpretation of language. In the students' writing process, the use of images (literary figures) played a symbolic role richly endowed with conceptual content. In seeking to nurture children's creative development, it is argued that teachers should adopt an

\begin{tabular}{|c|l|}
\hline STAGES & \multicolumn{1}{|c|}{ DESCRIPTION OF ACTIVITIES } \\
\hline $\mathbf{1}$ & $\begin{array}{l}\text { Short stories reading and generation of ideas from their content by brainstorming } \\
\text { and discussion. This activity was implemented in order to introduce literary } \\
\text { elements. }\end{array}$ \\
\hline 2 & $\begin{array}{l}\text { Students discussed about personal interests. The teacher remained in the } \\
\text { background during this phase, only providing language support if required, so as } \\
\text { not to inhibit students in the production of ideas. }\end{array}$ \\
\hline 3 & Students extended ideas into note form, and judged quality and usefulness of ideas. \\
\hline 4 & $\begin{array}{l}\text { Students organized ideas into a mind map, spider gram, or linear form. This stage } \\
\text { helped to make the (hierarchical) relationship of ideas more immediately obvious, } \\
\text { which helped students with the structure of their texts. }\end{array}$ \\
\hline 5 & Students wrote the first draft; this was done in class. \\
\hline 6 & $\begin{array}{l}\text { Drafts were presented to the teacher, so students developed an awareness of the } \\
\text { fact that a writer is producing something to be read by someone else, and thus can } \\
\text { improve their own drafts. }\end{array}$ \\
\hline 7 & Drafts were returned and improvements were made based upon teacher feedback. \\
\hline 8 & A final draft was written. \\
\hline
\end{tabular}

Table 1. Description of activities 
inclusive approach to pedagogy which fosters learner agency and autonomy (Jeffrey and Craft, 2004). By means of writing their short stories, the participants of this study expressed their inner experiences that revealed their personality and their creativity. Meanwhile, they discovered their ability as writers, which allowed them to construct texts in writing short stories.

In regards to the sub-question question, What features of literary language are present in ninth graders' short stories? It can be concluded that there are many possibilities for creation and interpretation. In fact, this is the most important element in students' growth as writers. Students used literary elements, such as figures (metaphors and similes), to show the particular scope of their interests, feelings and life experiences. When students use literary language, they showed that literary texts add new meaning to language, as well as reveal its inherently polysemic nature. It is clear that these literary texts have an important role in the growth and evolution of communication (Eco, 1992).

Through the analysis of student's samples, field notes, and interviews, two categories emerged. These instruments allowed the possibility to answer the research questions supported on the analysis of students' use of literary language in their short stories.

\section{Students' Perceptions as Writer}

The Writer's Self-Perception appears as the attempt to open up a new perspective on the relationship between personal reflection (processes of writing) and literature creation (authorial voice). Progress in the writing process should be understood in terms of clarity, organization and style. In other words, the writing process involves students' abilities to understand their thoughts, actions, and motifs when interacting with others through their texts. In this way, students' writing progress seeks a comparison between past and present performance in this competence. The students observed that they had developed their writing in different stages throughout the research study. This demonstrated the perceptions they hold about their own growth, strategies, and progress. As Bottomley (1998) points out, "specific progress" shows the dimensions of writing such as focus (interests), clarity (organization), style (narration), and coherence in developing experiences in writing practice and the strategies used by students to develop their writing (p. 288).

Quiero expresar cosas que me inquietan y a las que normalmente no doy importancia. Quiero representar realidades adversas a la vida, quiero mostrar todos aquellos defectos humanos contrastándolos con cualidades, que demuestra que la belleza humana no se deriva de un ser perfecto, que los problemas y los errores se convierten en enseñanzas. Quiero descifrar la vida a través de las letras. (IN-S1)

Quiero expresar las cosas que siento en cierto momento, y así mismo las cosas y experiencias que he vivido con la gente que me rodea. Quiero expresar también mi forma de ver la vida y mi futuro. (IN-S3)

At the beginning, students wrote about a topic they know or a specific moment in their lives without considering their audience. As mentioned before, students 
passed through different stages in order to write their short stories. At each stage, they acquired new information about writing. They also used what they already knew to make sense of new discoveries. Over time, they came to many understandings that led them to traditional writing with the help of the suggestions provided by the teacher's feedback. Indeed, the students brought their surrounding world experiences in writing their sort stories. They tended to express what was going on in their personal life. For example, the way they interact with their family and friends, personal conflicts, and their conceptions about the people where part of their immediate contexts.

\section{Literary Language Features}

This category is supported by the analysis of the short stories written by the students, and it reflects elements, such as literary figures (metaphors and similes), that appeared in their writings. Students studied and practiced these elements during eight English classes through workshops and readings in which some authors such as Hemmingway, Poe, and Wilde were analyzed, as well as literary language and comprehension of figures and styles. The way these elements were applied by the students was also observed. In this quotation taken from the field notes, we can see the way in which this student interprets the concept of literary language:

...la literatura es un lenguaje especial que permite que expresemos nuestros sentimientos y sensaciones de una manera particular... Siento que la literatura es una válvula de escape, pues nos permite ser libres en la expresión. (FN-S1) Para míla literatura es un medio de expresión, es comunicar ideas, pensamientos, sentimientos y situaciones que posiblemente no afrontamos en nuestra vida cotidiana. (FN-S2)

Literatura es para mí una forma de poder expresara través delaescritura, los sentimientos, pensamientos, ideas de una manera libre, es decir, utilizando cualquier género literario. (FN-S3)

Here, we can witness the impression that this student has about the personal concept of what literature is and her opinion about freedom of expression of ideas and feelings. Lazar (1993) stated that the act of interpretation presupposes two options at the same time: to think genuine things or to think from questions and doubt. From this, it can be said that literary language uses symbols, terminologies, concepts and styles in which the message has a particular meaning and a special conception.

There are a variety of features that allow us to distinguish the difference between literary and instrumental or common language. A literary text is that which demonstrates a use of literary language and the elements it uses to express and define the ideas of an author. The point here is that the language of literature cannot be defined by examining one particular work or focus on the body of the literature itself. Rather, literature is to be defined as a body of texts that regularly employ literary language. In this sense, the definition of literary language is in some fashion prescriptive as well as descriptive (Tambling, 1988). Thus, it can be asserted that features of literary language were 
present in the ninth graders' short stories. In the students' short stories, the use of literary language depended on the understanding of literary elements, such as figures (metaphor and simile), on the style of the narrative genre, and how these elements appeared in the texts. Such is the case with understanding metaphors and similes, as seen in the students' samples below,

"A painful hurts my heart but I'm here, living as always." Todo aquel que sufre tiene que "coger su cruz" y continuar adelante. (SS-S1)

"The long way of my life". Es como descubrir el destino. (SS-S2)

"The air of the forest reminds me the glory." Los sentimientos se ven reflejados en lo que intentamos demostrar (amor, tristeza, dolor, etc.). (SS-S3)

Similes:

"You'reolder than me, you look like my mother." (SS-S1)

"I saw him, We sat down in front of him and like a miracle success we also bought a lot of water and sodas (he was selling the sodas and the water)." (SS-S3)

Metaphors and similes entail the conception and the interpretation of contexts and realities that are described in a literary text. In students' short stories, the interpretative process is presumably compositional. That is to say, the writers showed their individual meanings of words (where this includes fixing the values of any contextually-sensitive terms) and syntax (Recanati, 2001, p. 265). Students who were familiar with the literary elements and who had an understanding of literary qualities could perceive themselves as writers.

\section{Conclusions}

When talking about literature as a vehicle to interpret the world, it is necessary to think of the role played by the use of literary language. In many cases, writing practice is conceived by students as a hard, and usually, boring activity. Despite this reality, the writing of short stories revealed the writers' inner experiences. Therefore, it is a tool for defining and interpreting realities and fostering selfcreativity.

By means of writing their short stories, the participants of this study expressed their inner experiences, which revealed their personality and perceptions they have as writers. The students, as authors of their own texts, used their creativity in order to invent settings and events, manipulate characters, and establish the sequence of the narration and conflict. This was done in contrast to just explaining, lecturing or demonstrating, which an important aspect of literary language. Thus, the purpose of literature, which is the enhancement of creativity and propagation of free interpretation, was achieved.

Besides, the concepts mentioned by Genette (1989) affirmed that language is the most important factor in shaping all our conceptions about life, ourselves, and the world. Rather than reflecting the "real world," language actually creates and structures our perceptions of "reality" (p. 55). Thus, the use of literary language promotes the whole scope of interests and situations that are important for students as writers to understand by means of their own short stories. 
Pennycook (1989) mentioned that teachers are "transformative intellectuals" who must see themselves as professionals who are able and willing to connect pedagogical theory and practice to wider social issues. This means that teachers should foster possibilities to use writing as vehicles of reflection on everything involved in students' lives with cultural aspects and personal thoughts in mind. Literature can be conceived as way to get to know and discover the world as a reader, as a well as a means to express thoughts and critical opinions when one writes. From this point of view, it is important to consider the development of abilities in analysis and interpretation (reading process), as well as the expression of ideas in written form (written production). The use of literary language helps students create texts and reflect about the aspects that are relevant for them.

In conclusion, the challenge that teachers have is the necessity to show the importance developing writing, generating possibilities of free expression, and promoting personal interpretation of contexts. Taking into account this point, it can be said that literature fosters these particular activities. In this case, the students' short stories were a special element in allowing self-expression.

\section{References}

Anderson, A., and Jones, N. (1986). TAFE curriculum research: A review of group process methods. Adelaide: TAFE National Centre for Research and Development.
Bakhtin, M. (1981). The dialogic imagination (M. Holquist Ed.). Austin, TX: University of Texas Press.

Barton, D., and Hamilton,M.(2000). Literacy practices. In D. Barton, M. Hamilton, \& R. Ivanovic (Eds.), Situated Literacies. Reading and Writing in Contexts (pp 7-15) London Routledge.

Bottomley, D. (1998). Assessing children's views about themselves as writers using the Writer Self-Perception Scale. The Reading Teacher, 51(4), 286-296.

Butler, A., and Turbill, J. (1984). Towards a reading writing classroom. Portsmouth, NH: Heinemann.

Cassany, D. (1995). Describir el escribir, como se aprende a escribir. Barcelona: Paidos Iberica.

Dinneen, K., and O'Connor, M. (1983). Elements of the Short Story. Retrieved from: http:/ / www.yale.edu/ynhti/curri culum/units/1983/3/83.03.09.x.html

Eco, U. (1981). Lector in fábula, la palabra en el tiempo. Barcelona: Lumen.

Eco, U. (1992). Interpretación y sobreinterpretacion de textos. Cambridge: Cambridge University Press.

Fokkema, D. (1985). The Concept of Code in the Study of Literature. Poetics Today, 6(4), 643-656

Freire, P. (1998). Pedagogy offreedom: Ethics, democracy, and civic courage (Clarke, P., Trans.). Maryland: Rowman \& Littlefield. 
Gee, J. P. (1991). What is literacy? Toronto: OISE Press.

Genette, G. (1989). Figuras III. Barcelona: Lumen.

Greenberg, K. (1987). Defining, teaching, and testing basic writing competence. Topics in Language Disorders, 7(4), 31-41.

Hemingway, E. (1987). The complete short stories of Ernest Hemingway. Finca Vigía Edition. New York: Scribner.

Hernández, R., Fernández, C., and Baptista, P. (2006). Metodología de la investigación ( $4^{\text {th }}$ ed.). México: Mc Graw Hill.

Hicks, D. (1996). Contextual inquiries: A discourse-oriented study of classroom learning. Cambridge, MA: Cambridge University Press.

Hopkins, D. (1995). A Teacher's Guide to Classroom Research. Buckingham, PA: Philadelphia Open University Press.

Hubbard, R., and Miller (1999). Living the Questions: A guide for teachers-researchers. Maine: Stenhouse.

Jeffrey, B., and Craft, A. (2004) Creative practice and practice which fosters creativity in L. Miller and J. Devereux (Eds.) Supporting children's learning in the early years (105-112). London: David Fulton.

Kennedy, J., and Gioia, G. (1999). Literature: An introduction to fiction, poetry, and drama. Ed. Harcourt.

Lazar, G. (1993). Literature and language teaching. Cambridge: Cambridge University press.
Liu, Y. (2009). The significance of structure in analyzing short stories. Asian Social Science Journal, 5 (8), 141-143

Merriam, S. (1985). The case study in educational research: A review of selected literature. Journal of Educational Thought, 19 (3), 204-217.

Miller, C. (1989). Writing Competency Statements in Communication. Edinburgh: Napier Polytechnic.

Mischler, E. G. (1986). Research interviewing. Context and narrative. Cambridge, MA: Harvard University Press.

Newton, J. (2001). Options for vocabulary learning through communication tasks. ELT Journal, 55 (1), 30-37.

O'Donoghue, B. (2001). What is literary language? (Why some words are more literary than others). A critical essay. The English Review, 4 (11) 28.

Osgood, C. (2005). The Measurement of Meaning. Urbana, IL: University of Illinois Press.

Pawlas, G.E. (1995). The structured interview: Three dozen questions to ask prospective teachers. NASSP Bulletin, 79, 62-65.

Pennycook, A. (1989). The concept of method, interested knowledge, and the politics of language teaching. TESOL Quarterly, 23 (4), 589 - 618.

Poe, E. A. (1993). Tales of Mystery and Imagination ( $2^{\text {nd }}$ ed.). Retold by Margaret Naudi. Oxford University Press: New York. 
Quintero, N., Cortondo, P., Menéndez, T., and Posada, F. (1995). A la hora de leer y escribir...textos. Argentina: AIQUE.

Quiroga-Clare, C. (2003). Language ambiguity: A curse and a blessing. Translation Journal. 7(1), 57-61.

Recanati, F. (2001). Literal/Nonliteral. Midwest Studies in Philosophy, 25, 264274.

Sharples, M. (1996). An account of writing as creative design. Hillsdale, NJ: Lawrence Erlbaum

Tambling, J. (1988). What Is literary language? Michigan: Open University Press.

White, R., and Arndt, V. (1991). Process writing. London: Longman.

Wilde, O. (1981). The nightingale and the rose. London: Kaye \& Ward.

Yin, R. (1989) Case Study Research: Design and Methods (rev. ed.). Beverly Hills, CA: Sage Publications.

Zonabend, F. (1992). The monograph in European ethnology. Current Sociology, 40 (1), 49-60. 